\title{
Analisis Implementasi Pelaksanaan E-Court di Pengadilan Agama
}

\section{Piousty Hasna Arifany*}

Prodi Hukum Keluarga Islam, Fakultas Syari'ah Universitas Islam Bandung Bandung, Indonesia.

*pioustyha14@gmail.com

\begin{abstract}
The research in this thesis is a type of content analysis and descriptive analysis. The data used in this study is primary data, namely interviews and secondary legal materials in the form of Perma No. 1 of 2019 concerning online case administration and the Letter of the Directorate General of the Religious Courts Agency, No. 5374/DJA/HM.01/X/2019. While the approach that the author uses is qualitative and normative-empirical. The author uses data collection techniques Literature Study, observation, interviews, and documentation. In the Letter of the Directorate General of the Religious Courts Agency, No. 5374/DJA/HM.01/X/2019 it has been explained that all Courts of First and Appeals within the Religious Courts immediately implement the e-court system as a follow-up to PERMA No. 1 of 2019. At the Bandung Religious Court, the e-court itself has been implemented since 2019, but the use of this e-court is deemed not optimal, during the COVID-19 pandemic situation, e-court can be a solution for litigation online in order to minimize crowds. The results of this study indicate that there are factors that hinder the implementation of ecourt at the Bandung Religious Court.
\end{abstract}

Keywords: E-Court, Bandung Religious Court, Covid-19.

\begin{abstract}
Abstrak. Penelitian ini bertujuan menganalisis kesesuaian implementasi pelaksanaan peradilan melalui ecourt di Pengadilan agama Bandung dengan Perma No 1 Tahun 2019 tentang Administrasi perkara secara online dan Surat Direktorat Jenderal Badan Peradilan Agama, No 5374/DJA/HM.01/X/2019. Penelitian ini bersifat normatif empiris. Dianalisis secara deskriptif. Data diperoleh melalui studi Pustaka, observasi, wawancara dan dokumentasi. Hasil penelitian menunjukkan bahwa implementasi pelaksanaan Perma No 1 Tahun 2019 tentang Administrasi perkara secara online dan Surat Direktorat Jenderal Badan Peradilan Agama, No 5374/DJA/HM.01/X/2019 telah dilaksanakan sejak tahun 2019. Namun dalam pelaksanaannya belum efektif akibat literasi masyarakat terkait e-court masih rendah.
\end{abstract}

Kata Kunci: Implementasi E-Court, Pengadilan Agama Bandung. 


\section{A. Pendahuluan}

Perkembangan teknologi semakin memanjakan masyarakat dalam mempermudah berbagai aktifitas sehari-hari. Aktifitas yang dahulu terkesan membuang banyak waktu dan biaya, kini dapat dinikmati dengan lebih mudah dan praktis tanpa merasa kerepotan. Salah satunya dengan fasilitas layanan online yang masyarakat nikmati sekarang.

Perma No 1 Tahun 2019 tentang administrasi perkara secara elektronik dengan aplikasi e-litigasi merupakan kelanjutan dari e-court yang diberlakukan untuk perkara perdata, perdata agama, tata usaha militer, tata usaha negara. Pada sistem e-court sebelumnya, sistem elektronik atau online hanya diberlakukan pada administrasi negara atau pendaftaran.

Selain itu, sistem elektronik juga tidak hanya diberlakukan pada pendaftaran perkara, pembayaran biaya perkara dan biaya pemanggilan tetapi diberlakukan juga dalam pertukaran dokumen jawab jinawab, pembuktian, dan penyampaian putusan secara elektronik. E-litigasi juga memperluas cakupan pengguna data peradilan secara elektronik. Pemberlakuan e-litigasi untuk persidangan di tingkat pertama juga diikuti dengan pemanfaatan e-court untuk upaya hukum banding, kasasi dan peninjauan kembali terhadap perkara yang menggunakan e-litigai pada tingkat pertama.

Peraturan Direktorat Jendral Badan Peradilan Agama Mahkamah Agung yang mengeluarkan surat dengan nomor 5374/DJA/HM.01/X/2019 pada tanggal 31 oktober 2019 tentang aplikasi e-court dengan fasilitas e-litigasi sudah dapat diakses dan digunakan di semua lingkungan peradilan termasuk Peradilan Agama untuk beracara secara elektronik. Pengadilan tingkat Banding dan tingkat pertama di lingkungan Peradilan Agama telah melakukan langkah-langkah sebagai berikut:

1. Menerapkan dan memanfaatkan aplikasi tersebut dalam penanganan perkara secara elektronik baik penggunan terdaftar maupun pengguna lainnya.

2. Pengadilan tingkat banding melakukan monitoring implementasi e-court termasuk elitigation di pengadilan dalam wilayah hukum masing-masing untuk memastikan kebijakan ini dapat berjalan dengan baik, dan apabila dalam pelaksanaannya mengalami kendala supaya dapat melaporkan ke Ditjen Badan Peradilan Agama untuk segera ditindaklanjuti.

Mahkamah Agung (MA) melalui Peraturan Mahkamah Agung (PERMA) Nomor 1 Tahun 2019 tentang Administrasi Perkara dan Persidangan di Pengadilan Secara Elektronik yang menggantikan PERMA No. 3 Tahun 2018 tentang Administrasi Perkara di Pengadilan secara Elektronik mengeluarkan sistem e-court.

E-court adalah sebuah instrumen peradilan sebagai bentuk pelayanan terhadap masyarakat dalam upaya untuk mewujudkan efesiensi pelayanan administrasi pengadilan. Sistem e-court diciptakan untuk mempermudah proses berperkara dan di dalam e-court tersebut terdapat fitur seperti pendaftaran perkara online (e-Filling), pembayaran panjar biaya online (e-Payment), pemanggilan elektronik (e-Summons). Tujuan aplikasi e-court dalam berperkara diharapkan mampu meningkatkan pelayanan dalam fungsinya menerima pendaftaran perkara secara online dimana para pencari keadilan akan menghemat waktu dan biaya saat melakukan pendaftaran perkara.

Masyarakat yang hendak beperkara di Pengadilan Agama Bandung tercatat dalam kepaniteraan Pengadilan Agama Bandung yang diakses dalam laman Sistem Informasi Penelusuran Perkara Pengadilan Agama (SIPP PA) Bandung. Perkara yang masuk pada bulan September 2020 sebanyak 898 perkara, yang terdiri dari perkara permohonan dan perkara gugatan. Menurut Panitera Pengadilan Agama Bandung Subai, menyatakan bahwa 898 perkara yang masuk pada bulan septermber 2020 terdapat hanya 8 perkara yang daftar melalui e-court. Adapun sisanya datang langsung ke Pengadilan Agama Bandung.

Berikut adalah tabel Daftar Penerima Layanan Meja E-Court pada Pengadilan Agama Bandung pada Bulan September 2020: 
Tabel 1.1 Tabel Daftar Penerima Layanan Meja E-court

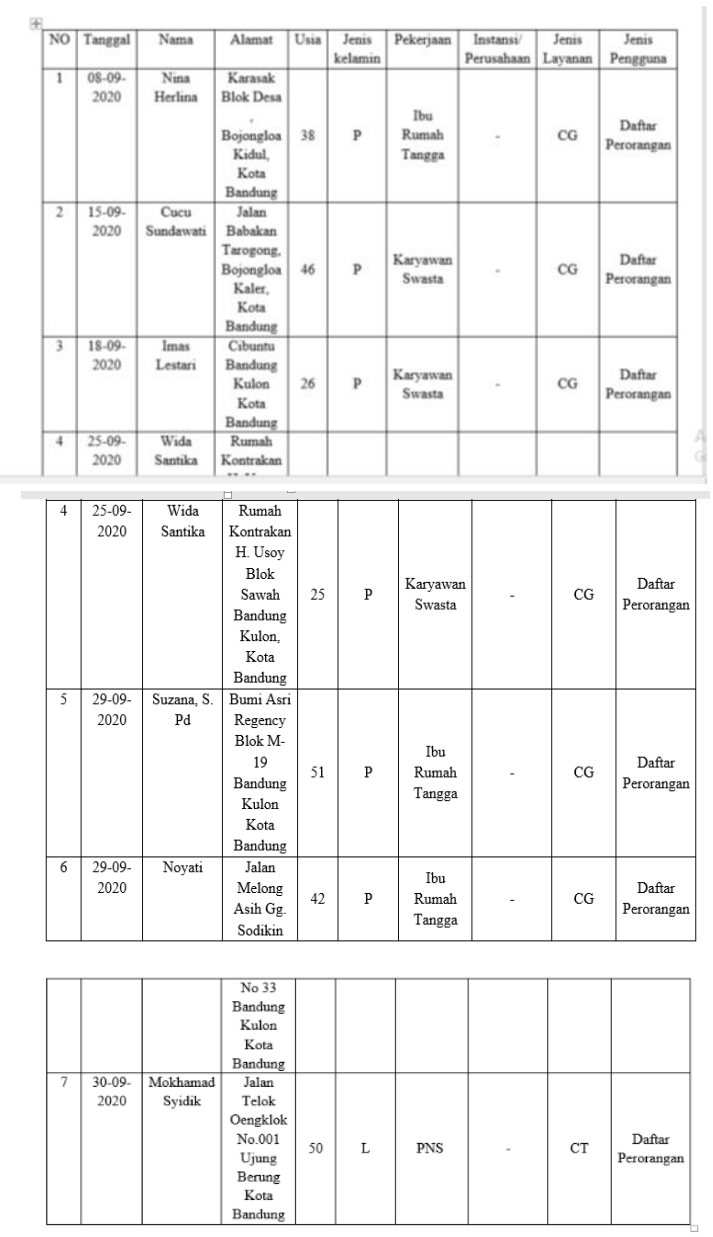

Seluruh masyarakat diharuskan untuk tidak keluar rumah mengingat situasi Covid-19 sekarang. Adapun aktivitas yang diperbolehkan keluar rumah hanyalah aktivitas yang sangat mendesak saja. Munculnya sistem E-court seharusnya bisa menjadi alternatif berperkara di rumah secara online dan menghindari adanya kerumunan, namun pada kenyataanya masih banyak masyarakat yang datang berbondong-bondong dan mengantri secara offline.

\section{B. Metodologi}

Penelitian ini bersifat kualitatif dan normatif-empiris, teknik pengumpulan data pada penelitian ini dilakukan dengan Studi Pustaka, observasi, wawancara, dan dokumentasi. Sedangkan teknik analisis data yang digunakan adalah Analisis Isi (Content Analisys) dan Analisis Deskriptif menggunakan model analisi yang dikemukakan oleh Miles dan Hubermas dengan tahapan Reduksi data, Penyajian data (display), dan Penyimpulan (Verifikasi). Tujuan penelitian ini untuk mengetahui implementasi e-court di Pengadilan Agama Bandung dan mengetahui faktor terhambatnya pelaksanaan e-court di Pengadilan Agama Bandung.

\section{Hasil dan Pembahasan}

Hasil yang diperoleh dari studi Pustaka khususnya terkait pengadilan secara elektronik (ecourt) adalah pada bulan Agustus 2019 Mahkamah Agung telah menerbitkan Peraturan Mahkamah Agung nomor 1 Tahun 2019 tentang Administrasi Perkara dan Persidangan di Pengadilan secara elektronik. Peraturan ini mengatur pada ruang lingkup Pengadilan Negeri, Pengadilan Agama/Mahkamah Syariah, Pengadilan Militer dan Pengadilan Tata Usaha Negara. Administrasi perkara dan persidangan di Pengadilan secara elektronik meliputi proses 
penerimaan gugatan, permohonan, keberatan, bantahan, perlawanan, intervensi, penerimaan pembayaran, penyampaian panggilan/pemberitahuan, jawaban, replik, duplik, kesimpulan, dan penerimaan upaya hukum.

Untuk dapat menggunakan layanan administrasi perkara secara elektronik, maka pengguna harus terdaftar. Yang dimaksud pengguna terdaftar dalam hal ini adalah advokat, dan penggunan lain (non advokat).

Tahapan pendaftaran perkara yang mesti dilakukan bagi pengguna terdaftar adalah sebagai berikut:

1. Memilih Pengadilan yang berwenang

2. Mengunggah (upload) surat kuasa

3. Mendapatkan nomor pendaftaran online (bukan nomor perkara)

4. Menginput data para pihak

5. Mengunggah (upload) dokumen gugatan/permohonan dan surat persetujuan principal untuk beracara secara elektronik

6. Mendapat perhitungan taksiran biaya panjar (SKUM) dan

7. Pengguna terdaftar melakukan pembayaran secara elektronik.

E-court mulai diberlakukan di Pengadilan Agama Bandung pada bulan Desember 2019. Namun pada awal pelaksanaan e-court di Pengadilan Agama Bandung yang dapat mendaftar secara elektronik hanya dikhususkan untuk advokat terdaftar saja, yaitu advokat yang sudah mendaftarkan akunnya ke Pengadilan Tinggi dan karena akunnya harus diverifikasi oleh Pengadilan Tinggi tersebut. Setelah keluar regulasi baru berupa Peraturan Mahkamah Agung terjadi peluasan kategori pendaftar. Awalnya hanya advokat saja setelah keluar regulasi tersebut, pendaftar akun perorangan dapat melakukan pendaftaran baik secara perorangan atau badan hukum. Namun untuk perorangan masih tetap dibantu oleh petugas Pengadilan Agama karena membutuhkan akun yang diverifikasi oleh pihak Pengadilan Agama. Suatu produk dapat dikatakan efektif jika terjadi keseimbangan antara output dengan input-nya. Pada Peraturan Direktorat Jendral Badan Peradilan Agama Mahkamah Agung yang mengeluarkan surat dengan nomor 5374/DJA/HM.01/X/2019 yang menginstruksikan semua Pengadilan Tingkat Pertama dan Tingkat Banding di lingkungan Peradilan Agama segera menerapkan sistem e-court sebagai tindak lanjut dari PERMA No. 1 Tahun 2019 tersebut. Sesuai dengan peraturan di atas Pengadilan Agama Bandung sudah melaksanakan penggunaan e-court dari bulan Desember 2019 dan berjalan sesuai arahan dan peraturan tersebut. Namun pendaftar melalui e-court masih sedikit. Pada bulan September 2020 tercatat yang mendaftar menggunakan e-court hanya 8 Perkara dari kurang lebih 800an perkara. Pengadilan secara elektronik (e-court) adalah suatu penyelenggaraan peradilan yang dilakukan untuk memenuhi asas peradilan yaitu sederhana, cepat, dan biaya ringan sebagaimana dinyatakan dalam Perma tersebut.

Hasil identifikasi terhadap jawaban wawancara yang dilakukan kepada tiga responden secara acak dapat disimpulkan bahwa faktor yang memengaruhi sedikitnya penggunaan ecourt oleh masyarakat dapat dikelompokkan 4 faktor, yaitu:

1. Keterbatasan pengetahuan masyarakat akan adanya E-Court.

Merujuk hasil sampel wawancara kepada 3 responden dari pendaftar langsung kepada Pengadilan Agama, ternyata mereka masih banyak yang tidak mengetahui e-court dan sistem cara kerja dan pelaksanaannya. Sekalipun Pengadilan Agama telah mensosialisasikan melalui website-nya akan tetapi masyarakat tidak pernah membuka website tersebut dan tidak mencari informasi apapun terkait tentang e-court. Pengetahuan adanya e-court melalui banner yang terpasang di sekitaran lingkungan Pengadilan Agama setelah mereka mendatangi dan mendaftar di Pengadilan Agama secara langsung. Padahal jika dibandingkan, biaya beracara menggunakan e-court hanya memakan biaya sekitar 100 ribu sampai dengan 200 ribu saja, apabila beracara secara langsung biaya pengadilan mencapai 250 ribu bahkan ada yang sampai 500 ribu. Berhubung kemampuan literasinya rendah, pengadilan melalui e-court tidak dilakukan sekalipun biayanya murah.

2. Keterbatasan perangkat aplikasi di handphone Masyarakat 
Berdasarkan hasil wawancara peneliti dengan pihak Pengadilan Bandung yaitu bapa Asep Kustiwa S.H selaku Panitera Muda Gugatan mengatakan bahwa Mendaftar secara elektronik ini membutuhkan data scanan, atau file datanya berupa PDF (Portable Document Format) dan Word, otomatis tidak setiap orang mempunyai aplikasi dan juga kurang paham cara kerja PDF. Kendalanya ada pada perangkatnya masyarakat. Masyarakat Indonesia kebanyakan ingin yang simpel yaitu dengan cara datang langsung ke Pengadilan Agama, artinya mereka mendapatkan infromasi secara langsung dan jelas untuk dimengerti.

3. Sulitnya membuat surat gugatan sendiri

Perbedaan dari masyarakat yang berperkara dengan menggunakan e-court dan tidak menggunakan e-court adalah layanan POSBAKUM (Pusat Bantuan Hukum). Masyarakat yang hendak berperkara langsung datang ke Pengadilan Agama yang tidak mampu membayar jasa advokat dan lain sebagainya akan diarahkan ke layanan Posbakum tersebut untuk dibuatkan surat gugatannya, lain halnya dengan berperkara menggunakan e-court. Mereka yang menggunakan e-court harus membuat surat gugatan sendiri dan diserahkan kepada Pengadilan Agama berbentuk file PDF (Portable Document Format). Posbakum Pengadilan adalah layanan yang dibentuk oleh dan ada pada setiap pengadilan tingkat pertama untuk memberikan layanan hukum berupa informasi, konsultasi, dan konsultasi hukum, serta pembuatan dokumen hukum yang dibutuhkan sesuai dengan peraturan perundang-undangan yang mengatur tentang Kekuasaan Kehakiman, Peradilan Umum, Peradilan Agama, dan Peradilan Tata Usaha Negara. Pada setiap Pengadilan dibentuk Posbakum Pengadilan. Pembentukan Posbakum Pengadilan dilakukan secara bertahap. Pengadilan menyediakan dan ruangan dan sarana/prasarana untuk Posbakum Pengadilan sesuai kemampuan dengan memperhatikan akses untuk penyandang disabilitas, perempuan, anak-anak, dan lanjut usia.

Sebagaimana telah dinyatakan pada bab sebelumnya, Posbakum Pengadilan memberikan layanan berupa : a). Memberikan informasi, konsultasi, atau advis hukum; b). Bantuan pembuatan dokumen hukum yang dibutuhkan; c). Penyediaan informasi daftar Organisasi Bantuan Hukum yang dimaksud dalam Undang-Undang Nomor 16 Tahun 2011 tentang Bantuan Hukum atau organisasi bantuan hukum atau advokat lainnya yang dapat memberikan bantuan hukum cuma-cuma (Prodeo). Oleh karena itu, idealnya Pihak Pengadilan Agama Bandung membuat layanan POSBAKUM secara online, agar masyarakat yang hendak memakai e-court bisa terbantu dengan adanya layanan POSBAKUM secara online ini, yang nantinya tujuan pelaksanaan e-court dapat tercapai dengan baik.

4. Pihak Pengadilan belum maksimal melakukan sosialisasi tentang E-Court secara langsung kepada masyarakat

Pihak Pengadilan Agama Bandung belum pernah melakukan sosialisasi kepada pihak masyarakat secara luas dan langsung. Sosialisasi yang dilakukan melalui website, melalui banner-banner, dan secara langsung ke masyarakat pendaftar secara langsung pada saat awal covid-19 mulai merebak di bulan Maret 2019. Setiap masyarakat yang daftar ke Pengadilan Agama Bandung diarahkan untuk berperkara secara elektronik, jadi tidak menggunakan brosur.

5. Keterbatasan sarana pendukung e-court dan ekonomi

Pengadilan melalui elektronik diperlukan sarana dan parsana yang memadai. Seperti ketersediaan jaringan internet hingga pelosok daerah, kestabilan jaringan yang dimiliki masyarakat dan Pengadilan Agama, ketersediaan kuota masyarakat. Faktor-faktor ini menjadi penghambat dalam penyelenggaraan e-cout di Pengadilan Agama.

\section{Kesimpulan}

Pelaksanaan e-court di Pengadilan Agama Bandung sudah sesuai dengan PERMA No 1 Tahun 2019, namun dalam penyelenggaraannya masih kurang efektif akibat sosialisasi dari pihak 
Pengadilan Agama Bandung masih sebatas ditayangkan di website, pemasangan banner di sekitar pengadilan, pengarahan secara lisan saat pendaftar perkara datang ke Pengadilan Agama. Literasi masyarakat pendaftar e-court masih rendah serta ketidakstabilan jaringan internet di masyarakat.

Faktor-faktor yang menyebabkan terhambatnya efektifitas e-court adalah a) Literasi masyarakat terhadap e-court masih sangat rendah walaupun banner sudah dipasang di lingkungan Pengadilan Agama Bandung; b) Keterbatasan kepemilikan perangkat hardware dan software masyarakat yang memadai antara seperti aplikasi pada HP, Laptop/computer, scanner, perangkat software lainnya; c) Keterbatasan operasionalisasi aplikasi yang diperlukan dalam penyelenggaraan e-court. Tidak semua masyarakat paham semisal cara kerja mengubah word ke PDF; d) kebanyakan masyarakat menginginkan yang simple dengan cara datang langsung ke Pengadilan Agama; e) Sulitnya membuat dan menyusun gugatan sendiri dan mengupload mengupload gugatan/permohonan; f), Pihak Pengadilan Agama belum maksimal melakukan sosialisasi kepada masyarakat terkait e-court. Baru dilakukan melului website dan baner di sekitar Pengadilan Agama bandung.

\section{Daftar Pustaka}

[1] Djatmiko, H., 2019. Implementasi Peradilan Elektronik (E-Court) Pasca di Undangkannya Perma Nomor 3 Tahun 2018 Tentang Administrasi Perkara di Pengadilan Secara Elektronik. Jurnal Legalita, Volume 1, p. 24.

[2] Aidi, Z., 2020. Implementasi E-Court Dalam Mewujdukan Penyelesaian Perkara Perdata Yang Efektif dan Efisien:. Jurnal Masalah-Masalah Hukum, Volume 1, p. 81.

[3] Susanto, M. I. W. S., 2020. Muhamad Iqbal, Wawan Supriyatna, Menciptakan Sistem Peradilan Efesien Dengan Sistem E-Court Pada Pengadilan Negeri dan Pengadilan Agama Se-Tangerang Raya. Jurnal Cendekia Hukum, Volume 6, p. 105.

[4] Muhammad Yunus, F. F. R. S. H. , G.K.S, 2018. Fahmi Fatwa Rosyadi Satria Hamdani, Gusti Khairina Shofia, Tinjauan Fiqih Muamalah Terhadap Akad Jual Beli Transaksi Online Pada Aplikasi Go-Food,. Amwaluna : Jurnal Ekonomi dan Keuangan Syariah, Volume 2, p. 145.

[5] Masyarakat Pengadilan Agama Bandung, 2021. Pelaksanaan E-court [Wawancara] (Maret, 2021). 